\title{
UTILIDAD DEL SERODIAGNÓSTICO DE LEPTOSPIROSIS EN EQUINOS APARENTEMENTE SANOS
}

\author{
Schmeling, M. F. ${ }^{1}$; Arn, E. ${ }^{2}$; De Marco, P. L. ${ }^{3}$ \& Vanasco, N. B. ${ }^{1,4}$
}

\begin{abstract}
RESUMEN
La mayoría de las infecciones por leptospiras en equinos son inaparentes no se reconoce la fase aguda febril sino la secuela de la enfermedad, la uveítis recurrente, pudiendo ésta conducir a la ceguera. El objetivo de este estudio fue evaluar la utilidad del serodiagnóstico de leptospirosis en equinos aparentemente sanos. A cada uno de los 61 animales incluidos en el estudio se les realizó microaglutinación (MAT), oftalmoscopía y completó una ficha clínico-epidemiológica. La seroprevalencia hallada fue del 62,3\% (38/61). El serogrupo más reaccionante y con mayores títulos fue Pomona seguido de Sejroe e Icterohaemorrhagiae. Equinos con $>=4$ años presentaron prevalencias de infección superiores que aquellos con $<4$ años $(\mathrm{p}=0,0064)$. La seropositividad fue mayor en animales con lesiones oculares que en aquellos sin lesiones $(\mathrm{p}=0,046)$. La serología, además de ser útil para conocer la prevalencia de infección, podría emplearse para detectar precozmente enfermedad ocular crónica en equinos aparentemente sanos.
\end{abstract}

Palabras clave: leptospirosis, serodiagnóstico, equinos, uveítis.

\section{SUMMARY}

\section{Leptospiral serodiagnosis Utility in apparently healthy horses}

Most leptospiral infections in horses are unapparent, causing chronic illness and recurrent uveitis rather than the acute illness and fever. The objective of this study was to assess the ussefulness of leptospiral serodiagnosis in apparently healthy horses. Serum samples from 61 animals were examined by means of microaglutination test (MAT), ophthalmoscopy and clinical-epidemiological history. The seroprevalence obtained was $62,3 \%$ (38/61). Pomona was the most reacting serogroup followed by Sejroe and Icterohaemorrhagiae. Horses $>=4$ years old had a higher serological prevalence than horses $<4$ years $(p=0,0064)$. Seropositivity was higher in animals showing ocular lesions than in horse with no lesions $(p=0,046)$. Further research is needed to assess the usefulness of serology to predict the blindness.

Key words: leptospirosis, serodiagnosis, equine, uveitis.

1-Instituto Nacional de Enfermedades Respiratorias (INER) "Dr. Emilio Coni”. Administración Nacional de Laboratorios e Institutos de Salud (ANLIS) "Dr.Carlos G. Malbrán”. Blas Parera 8260, Santa Fe.

3-Facultad de Ciencias Veterinarias (UNL), Esperanza, Santa Fe.

4 -Facultad de Bioquímica y Ciencias Biológicas (UNL), Santa Fe, Santa Fe.

Manuscrito recibido el 22 de septiembre de 2009 y aceptado para su publicación el 18 de noviembre de 2009. 